\title{
COVID-19 in a Day Care Centre from the Perspective of the Employees Josef Nota
}

DOI: $10.32725 /$ cetv.2021.017

\begin{abstract}
:
The researched issue is the impact of infection caused by a new type of coronavirus in the environment of a day care centre. The importance of the issue is given by the fact that the topic directly concerns the lives of all actors connected with the environment offering social services. The purpose was to use the stories obtained from the helpers in order to look at the subjective picture which shows the current situation of the actors. With the onset of the pandemic and the introduction of anti-pandemic measures, they are coming into a specific situation and are facing (up to now) an unknown challenge. The aim of this paper was to use qualitative research tools in order to capture the authentic statements of respondents in a particular environment and try to avoid purposeful interpretations to which the topic may lead. In addition to the description of the stories of the respondents, the study also presents seven key topics arising after data collection and subsequent coding. The argumentation depends on the attitude of the interviewed respondents. The conclusions of the qualitative study offer a starting point for understanding the current serious situation, give the opportunity to understand the phenomenon in a more comprehensive form of authentic statements, and can be used for research into possible impacts of coronavirus crisis on actors in day care centres.
\end{abstract}

Keywords: COVID-19, employees, day care centre, social services, helping professions, senior, anti-pandemic measures, qualitative research

\section{Research Problem and Research Question}

The workplaces with the highest risk in connection with the spread of coronavirus infection are, among others, facilities providing social services to their clients. The problem is not just the easy spread of the disease in the community-like environment. At the same time, these facilities care for a group of clients who are immediately endangered by a possible infection of a new type of virus due to their greater susceptibility to a worse course of the COVID-19 disease. ${ }^{1}$

1 Cf. (C) Covid portál, 'Návštěvy sociálních zařízení. Pravidla a doporučení', (online), available at: https://covid.gov.cz/situace/nemocnicesocialni-zarizeni/navstevy-socialnich-zarizeni, updated $7^{\text {th }}$ December 2020, cited $5^{\text {th }}$ February 2021. 
The examined day care centre ${ }^{2}$ is a facility that was probably among the most affected by coronavirus in the region. ${ }^{3}$

The aim of this article is to understand how the employees of the selected DCC perceive and experience this difficult situation and why they perceive it in such a way. The research was perceived through the subjects of the research problem (in this case to the centre educators).

The main research question formulated is: How are the current situations emerging in connection with the COVID-19 epidemic experienced by day care centres?

\section{Design and Research Method}

With regard to the formulated research question, a qualitative approach to the investigated phenomenon was chosen, as the question asked is about the discovery of some not entirely clear phenomena. ${ }^{4}$

The respondents are two specific DCC employees who work as activation workers in social services'. At the same time, they are students of the leisure education programme at the Faculty of Theology at the University of South Bohemia.

The data was based on the fact that the respondents wrote open-form essays ${ }^{5}$ during one semester, and the core message of these essays became the basis for an in-depth, unstructured interview. It was based on a basic research question. The form of the supplementary questions is not relevant for the design of the research, as the supplementary questions were asked in order to gain a deeper understanding of the message and took place spontaneously and naturally on the basis of the narratives of the respondents. The data obtained during the interviews were recorded, then transcribed verbatim, and then analysed. The purpose of the analysis was to process the data in a meaningful way and find the answer to the question asked. Open coding was chosen for analysis. The resulting codes were then grouped (categorised) into terms that belonged to the same phenomenon, and then interpreted in order to understand the phenomena that arose during the process.

\section{Research Data and Survey Ethics}

The data is based on the authorial essays which helped to formulate the basic research question, and especially on in-depth, unstructured interviews which were conducted in order to find an answer to the research question. ${ }^{6}$ The names of the respondents were anonymised for ethical reasons, and the mentioned workplace is named and presented only in a general way. The respondents agreed with the research and the final version of the article was provided to them in order to receive their approval.

\section{Issues Concerning Quality and Interpretation of the Research}

The initial impulse for the formulation of the basic research question and research in general was the information obtained from the authorial essays of two respondents. After analysing the essays,

\footnotetext{
Hereinafter referred to as DCC, or 'centre'.

The name of the region is not given for ethical reasons.

Cf. Roman ŠVAŘÍČEK and Klára ŠEĎOVÁ, Kvalitativní výzkum v pedagogických vědách: Pravidla hry, Praha: Portál, 2007.

It has been proven by the practice that for the purposes of qualitative research it is more advantageous when students' authorial texts are not evaluated in terms of form and content. They are just submitted or not submitted. This concerns the repeated experience made within the course of a particular study programme.

6 Cf. Roman ŠVAŘÍČEK and Klára ŠEĎOVÁ, Kvalitativní výzkum.
} 
the basic research question was formulated and unstructured interviews were conducted with the respondents.

Triangulation was used not in the context of efforts to strengthen the validity of the collected data (by placing two different methods against each other), but in the second sense, that is, as a strategy upporting knowledge through the acquisition of additional information. ${ }^{7}$ Data gained from essays and in-depth interviews are therefore not artificially isolated; the final message presented to the reader is a form created by the synthesis of all the data obtained.

The intention was to avoid two issues in the interpretation of the data. These were supporting the researcher's preconceived notions and the well-known phenomenon of qualitative studies called 'overinterpretation' (the ambition to find something in the data that is not really there and to project one's implicit theories into them). The communication aimed at answering the research question focuses on the statements of the respondents, as this is desirable in the area of qualitative research. ${ }^{8}$

The limit of the research is the data obtained from two respondents only. With regard to the amount of data obtained, a reduction was necessary.

The personal data of the respondents are given intentionally: we believe that a closer description of the respondents helps to understand the contextual logic of the qualitative survey.

\section{Theoretical Framework of the Problem}

The phenomenon is studied in the environment of social services. A simplified definition of social work would be defined as follows: it is a specifically focused activity aimed at helping people in non-standard and difficult life situations. ${ }^{9}$ In professional publications, this profession is commonly associated with the reflection of the ideals of society. ${ }^{10}$ Assisting professions can be defined by a relatively simple characteristic. Namely, they are characterised by working with people. It is a whole range of professions, whether medical, pedagogical, or social. ${ }^{11}$ Within the helping professions, the human relationship plays a central role. This aspect distinguishes the helping professions from other professions in which social interaction appears. ${ }^{12}$ At a broader level, the human relationship is considered a basic 'tool' when exercising this profession. ${ }^{13}$

Social services are professionalised: the aim is to train qualified social workers whose expertise is declared by being able to apply knowledge from various disciplines (sociology, psychology) in practice and who are competent to work with a specific person. ${ }^{14}$

Social services can have a residential, an outpatient, or a field character. A DCC usually focuses on the provision of residential services with the provision of food and health and social care. DCCs are classified in different ways.

The most numerous groups of recipients of social services include the elderly, people with disabilities, families with children, but also people who, for various reasons, live 'on the margins'

Cf. Michal MIOVSKÝ, Kvalitativní prístup a metody v psychologickém výzkumu, Praha: Grada, 2006.

Cf. ibid., p. 203.

Cf. Stibor HATÁR, Sociálna pedagogika, sociálna andragogika a sociálna práca - teoretické, profesijné a vztahové reflexie, Praha: Česká andragogická společnost, 2009, p. 75.

10 Cf. Zuzana HAVRDOVÁ, Kompetence v praxi sociální práce, Praha: Osmium, 1999, p. 9.

11 Cf. Jiří JANKOVSKÝ, Etika pro pomáhající profese, Praha: Triton, 2018, p. 9.

12 Cf. Karel KOPǨIVA, Lidský vztah jako součást profese, Praha: Portál, 2013, pp. 25-26.

13 Cf. ibid., pp. 14-15.

14 Cf. Igor TOMEŠ, 'Sociální politika, sociální služby a sociální práce', in: Základy sociální práce, ed. Oldřich MATOUŠEK, Praha: Portál, pp. $179-180$. 
of society. ${ }^{15}$ According to Act No. 108/2006 Coll., DCC users are provided with the following services: provision of food; provision of accommodation; helping with personal hygiene or provision of conditions for personal hygiene; helping with managing the usual tasks of self-care; social therapeutic activities; upbringing, educational, and activation activities; arranging contact with the social environment; and assistance in exercising rights, legitimate interests, and in procuring personal matters. Education and upbringing should be provided in the centres where there are children and young people. Adult users of centres, in turn, are provided (taking into account their possibilities) with a job. ${ }^{16}$

At the time of writing this article, the abnormal situation connected with the COVID-19 pandemic was quickly filling the pages of professional foreign and domestic journals. The issue of the impact of the COVID-19 pandemic is often mapped in studies and university dissertations using the tools of economics. ${ }^{17}$

These are mainly research surveys (the focus is on structured questions) which were conducted for the initial assessment of the situation and to reflect the impact of the epidemic on social services. ${ }^{18}$ We can mention the survey conducted by Institut sociální práce (the Institute of Social Work) in cooperation with the NMS Market Research agency (respondents answered several closed questions and one open question). ${ }^{19}$

The topic concerns, for example, 'Combating exclusions and ageism for older people during the COVID-19 Pandemic' (The Galway appeal) which contains four statements: (1) 'State and community responses to COVID-19 must be cognisant of direct exclusions that impact older people as a result of policies and strategies implemented to combat the virus, and where possible account for these negative circumstances through supports and action.; (2) 'We must continue to ensure that treatment for COVID-19, and other forms of resource allocation associated with the crisis, are based on need, and not a simple age threshold.; (3) 'In implementing polices and strategies to protect older people during COVID-19, we must not ignore the heterogeneity of the older population and frame older individuals as highly vulnerable, passive agents, ignoring their contribution during the pandemic.'; and (4) 'Policy and strategies combating COVID-19 must not be based on a problematisation of ageing and older people in the context of the crisis, or function to destabilise the considerable solidarity currently being witnessed across the generations. ${ }^{20}$

The core of the discussion about the results of our research will also be the report of the working group of the Rada vlády pro duševní zdraví (Government Council for Mental Health) which initiated an investigation into the impact of the crisis caused by COVID-19 on the mental health of the Czech population. ${ }^{21}$

Considering the implemented qualitative surveys, we can mention Holmajerovás final work

15 Cf. Jan MICHALÍK, Smluvní vztahy v sociálních službách, Olomouc: VCIZP, 2008.

16 Cf. Iva ŠVARCOVÁ, Mentální retardace, Praha: Portál, 2006.

17 Cf. Alexandra BOYARKINA, 'Analysis of the Economic Impact of COVID-19 on the Hospitality Industry in the Czech Republic', (online), available at: https://theses.cz/id/ssqe7r/, cited 16 ${ }^{\text {th }}$ April 2021. Michal HAMPEJS, Dopad COVID-19 na lidský kapitál (on-line), available at: https://theses.cz/id/rbf910/, cited $18^{\text {th }}$ April 2021.

18 Cf. Pavel KLIMENT and Lenka NÁDVORNÍKOVÁ, 'Prvotní reflexe dopadu pandemie koronaviru na sociální služby v ČR', Fórum sociální práce 2/2020, pp. 20-28.

19 Cf. @ 'Stručná interpretace výsledků výzkumu Institutu sociální práce realizovaného ve spolupráci s agenturou NMS Market Research', (online), available at: https://zitdoma.cz/wp-content/uploads/sites/2/2020/09/TZ_ISP_Interpretace_vysledku.pdf, cited $19^{\text {th }}$ April 2021.

20 () 'Combatting exclusions and ageism for older people during the COVID-19 Pandemic: Four Key Messages', (online), available at: http://rosenetcost.com/combatting-exclusions-and-ageism-for-older-people-during-the-covid-19-pandemic/, cited $18^{\text {th }}$ April 2021.

21 Cf. ( ) 'Dopady krize způsobené koronavirem SARS-CoV-2 a duševního zdraví populace ČR - zpráva pracovní skupiny Rady vlády pro duševní zdraví, (online), available at: https://www.mzcr.cz/wp-content/uploads/2020/01/Dopady-krize-zp\%C5\%AFsoben\%C3\%A9koronavirem-SARS-CoV-2-a-du\%C5\%Alevn\%C3\%ADho-zdrav\%C3\%AD-populace-\%C4\%8CR.pdf., cited $20^{\text {th }}$ April 2021. 
focused on the life experiences of seniors living in their own household, who have limited contact with others due to anti-pandemic measures. Based on a qualitative survey, she categorised five main topics. Using these, she tried to answer the research question ("life goes on, one cannot do anything about that, I have to die from something'; the lasting stability in a senior's life despite the instability of the situation; preserving the unity with your close ones as a defence against the feeling of social isolation; subjective perceptions of the environment suddenly become more negative and measures help but harm as well). However, this final thesis does not fully address the issues addressed in this paper, as it examines respondents from different backgrounds (own household / DCC). In addition, it reports on the attitudes of healthy women over 65 who are without a real-life experience with the coronavirus infection. ${ }^{22}$

\section{Introduction of the Specific DCC}

The aforementioned home provides services for clients who have reduced self-sufficiency due to age or disability. Therefore, they require regular assistance from others, including the provision of social services (accommodation, meals, and care in the residential facility). The centre accepts mentally and physically handicapped clients from the age of 27 . The second, very large group are seniors. In the second wave of the epidemic, the vast majority of clients and almost half of the staff became infected in the centre. ${ }^{23}$

To understand the situation in this particular centre, the testimonies of two respondents will help us. They are colleagues in the centre, but each works with a different group of clients and in a different department. Their different professional experience offers the opportunity to see the researched phenomenon more comprehensively.

\section{The Story of Respondent No. 1}

Respondent No. 1 graduated from an upper high school which teaches pedagogy (15-18 years). She is the mother of two children and has been working in the educational sector for eight years. Respondent No. 1 applied for a job in the aforementioned DCC, and waited five years in order to gain a position as an 'activation worker in social services' in the seniors' department.

Her job is to develop the fine motor skills and manual skills of clients. She organises leisure activities, participates in their implementation, and ensures cultural and hobby activities for clients. She deals individually with clients who need psychological help. In her authorial essay at the end of January, she formulated a story that became the theme for another, unstructured interview and for a narrative interview. All the data, in a condensed, reduced form, illustrate a section of the story recording the spread of the disease in the DCC:

Respondent No. 1: The first signals that everything was not right came right after the weekend elections in 2020 from the kitchen of the centre. Some mentally disabled clients helping in the kitchen unfortunately spread the infection throughout the facility. The source of the disease was one of the cooks there. A colleague who works with me as an activator was tested positive, and I thought I was 'in the same boat'. I had strong headaches and back pain. The negative test convinced me otherwise, though. In the end, I only had a blocked cervical spine, supposedly from stress. I had to wear a neck

22 Cf. Eva HOLMAJEROVÁ, 'Životní zkušenost s omezeným kontaktem seniorů ve vlastní domácnosti a jejich prožívání protiepidemických opatření, (online), available at: https://is.muni.cz/th/nqk1a/, cited $20^{\text {th }}$ April 2021.

23 Given the nature of the sensitive data treated here, it is necessary to present this DCC in general only. 
collar for a while and avoid a lot of movement. It was even worse for me to stay at home and watch everything from a distance. The disease gradually spread throughout the centre.

Seventeen clients died in three weeks. I mourned most of them. The truth is that it is just a job, but I have been working there for four years and I consider most of my clients my family. I will no longer see (name), mentally at the level of a five-year-old child, shouting at me coffee! Coffee! I will not meet the lady (name) who was amazing, funny, and nice, and other people. How one is helpless and desperate due to not being able to help. And the next day another person passes away...

I know a lot about them. What kind of life they had, what kind of suffering with children they went through, what kind of illness they had, what kind of partner they lived with... I did not have to work in a protective suit in which one sweats unimaginably. I did not have to help them during fevers and diarrhoea, like a colleague who worked as a bedside nurse. I did not have to be right there when our clients were dying. Most of them died right at the centre. But the despair caused by unnecessary death is terrible anyway. Among them, there were people who were less than seventy years old, diagnosed with high blood pressure or diabetes only. Otherwise, they were fine.

After three weeks, I returned to work and tried to make the day more pleasant for all the clients. We started with the activities slowly, had fun with the songs. We tried to forget that, in fact, we could not go anywhere at all.

Most of the clients suffer from the fact that the family cannot see them. And Skype does not tell them much. If someone is ninety, seeing his daughter on the screen for half an hour without real touch and laughter will not inspire him much. Most clients need touch. When skyping, they usually hold my hand and they do not want to let me go even after that.

Unfortunately, after a week and a half at work, despite using protective equipment, I also got infected with covid. Fortunately, I only had a milder form: fever, muscle aches, and headaches. I was home for fourteen days and I am going back to my clients tomorrow. (...).

\section{The Story of Respondent No. 2}

Respondent No. 2 graduated with a high school diploma. Her field of study was specified as Family School - Economic and Administrative Services. After graduation, she studied at a language school focusing on the German language. She did not complete her studies of German language with a focus on education at the Faculty of Education for family reasons. She is married and is raising two children with her husband.

After reading all the essays of Respondent No. 2 and after conducting an unstructured interview, I asked the respondent a few additional questions that arose during the transcription of the interviews. Respondent No. 2 wrote another of the authorial essays. It was very authentic and open. I present only some personal data stated in the essay.

In her story, she describes that she has lived in the company of a senior since she was a child (she took care of her grandfather in addition to other family members). At a time when her grandfather's health became worse and the informant was unable to provide all the necessary care for him, he was admitted to a centre providing social services.

Later - after her first child was born - she joined the aforementioned DCC and obtained the position of 'activation worker in social services' in the seniors' department (that is, she has the same position as the Respondent No. 1).

Respondent No. 2 worked in the seniors' department for a year and a half. Her work included activation therapies, for example, a ceramic and art workshop, reading with seniors, sitting dance, 
and, especially, musical activities.

When one of the colleagues from the department of the 'younger clients' (30-60 years, clients with health and mental disabilities) left, she took over her position. She has been working as an activation worker in the department of clients with health and mental disabilities since then.

Respondent No. 2 described the situation influenced by the pandemic at her workplace in the following authorial essay (Respondent No. 2: 'This essay was easy to write. One did not have to think about it for a long time. I just described the reality, the life situation.'). The story was shortened again and the message reduced for the purposes of the research question.

Respondent No. 2: It was after the weekend. One by one, my co-workers went on sick leave. There was the suspicion of COVID-19 or other diseases. At the same time, it was forbidden to go outside the premises at our centre. Due to the COVID-19 disease, the canteen staff remained in quarantine. Unfortunately, they were the only option for clients who wanted to buy something. At that moment, a real bustle began. I stayed in the education department alone. So it was up to me. Three times a week I had to buy necessary things (cigarettes, food, cosmetics) for clients. Clients' families were calling to see if they could connect with them via Skype. One cannot say no to them. During the first wave we noticed that contact with the family was very important for our seniors (unfortunately for some of them, it was the last contact). And so I was running around while doing shopping, skyping, organising people's money with shopping, disinfecting everything possible, picking up phones, etc.

I must admit that I went 'as far as it goes'. And the moment I heard the phrase 'we have 6 positive clients' from the corridor, it was as if the world just stopped. Then it was just a struggle for time, to save as many people as possible from infection.

In the evening, I returned to my family exhausted, mainly mentally. My thoughts were still with our seniors. I was wondering whether or not the infection would stop. During my exhaustion, I did not admit to myself that I had any signs of symptoms at all. And after mass testing, I was quite surprised by the text of the incoming SMS with the positive results: 'pac. MH, PCR POZITIVNI'. At that point, I realised that I was going to have enough time and that I was going to spend a few days in the company of my family. On the one hand, I considered it a sign that it was time to slow down and be with my loved ones, to play a board game, to have coffee with my husband in peace, and to study. On the other hand, my thoughts were still with our seniors. I was thinking about what was happening in the centre.

Last but not least, I had concerns over health. It was not about me but about my father. At that time, he had had cancer treatment and was living in the same house. I immediately forbade him to visit our household. However, I saw how sad he was when he could not have daily contact with us like before, and especially with his grandchildren. Phone calls had to make up for visits. We were calling from the first floor to the ground floor and vice versa. It was a strange situation. We waited anxiously for the test results of the rest of my family. Unfortunately, my husband and daughter were also positive. Thank God our son - an asthmatic - and my father (after the cancer treatment) were negative. Thus, the crisis in our family was averted for a while. For the first time in a long time, I felt relieved.

However, I was still watching the spread of the disease in the Czech Republic and the television and radio reports from my workplace. Out of (number) clients, there were (number) infected. Considering employees, it was (number) out of (number). It hit me hard and I shed tears. Seeing the municipality, the place you visit every day, and the people you love in public, it was a very powerful experience. As soon as I was better, I felt the need to get back to work and be helpful where needed. The fear of 
returning to the centre after two weeks was enormous. Mainly because there was a possibility of not seeing some clients in the centre. This, unfortunately, was true. Deaths continued to rise not only at home, but also in the country. (...).

These two stories described in the written essay serve as an authentic image illustrating the situation in the DCC. The following chapters will be devoted to key topics that arose after data collection from in-depth, unstructured interviews based on open coding and categorisation.

The aim was to make sure that the additional comments in the following chapters were not simplistic interpretations. The core of the message indented for the reader was to be quoted, authentic statements. ${ }^{24}$

\section{Anti-pandemic Measures and Impacts of Insulation}

Due to the COVID-19 pandemic, the director of the centre banned clients' visits and walks outside the centre premises until further notice. In an unstructured interview, Respondent No. 1 mentioned the issue of isolation as absolutely essential:

Respondent No. 1: Our clients are losing their zest for life but that also can happen to ordinary people who do not have to be locked up here. Clients are definitely becoming much more annoyed, and it is logical. They can only go to the park next to the institute (and thank God at least for this option, as otherwise they would be closed in the building only). The limited mobility is definitely depressing. In addition, I believe that in some clients with a disrupted mind, the psychiatrist had to prescribe stronger medication.

Respondent No. 1 mentions that at her workplace, the seniors' department, clients find it very difficult to handle separation from relatives.

Respondent No. 1: Those who were used to seeing their relatives on a regular basis have difficulty with separation. Before COVID-19, relatives visited them regularly, twice, three times a week. Their grandchildren were taking turns. These seniors find it very difficult to isolate themselves from direct contact with relatives.

Respondent No. 2, working with a group of clients with mental disabilities, also notes the effects caused by the closure of the premises of the centre.

Respondent No. 2: It is definitely challenging for clients and their families. Although we want to protect them against the disease, it is clear that the measures do not suit them at all. For example, a gentleman who used to walk several kilometres a day can only walk in the park (albeit it is large) now. He therefore becomes aggressive and attacks us. He used to go for a walk right after his breakfast, and then he was calm. He is currently de facto heavily restricted and can only walk through the park. It has a bad impact on him as he cannot leave the complex.

However, Respondent No. 2 is of the opinion that anti-pandemic measures affect a group of seniors qualitatively differently than 'her' group of clients with mental disabilities.

Respondent No. 2: In the case of clients with mental disabilities, I feel that the measures will not be so painful for them. Especially individuals who have lived in institutional care from an early age probably suffer from different things than the pandemic situation in the Czech Republic. But seniors are the ones who really experience this situation terribly.

Of course, in our group, clients with mental disabilities ask when they will be able to go out. It does not bother them though. I will give an example: they ask about when they will be allowed

24 Cf. Kristin ESTERBERG, Qualitative methods in social research, Boston: McGraw-Hill, 2002. 
to go out, but they do not care about the answer. Very often they do not even wait for my answer. From the employee's point of view, the situation has changed terribly due to the pandemic. From the point of view of a client with a mental disability, however, the situation apparently has not changed dramatically.

The most difficult thing was to explain to clients with mental disabilities what was happening, what situation we found ourselves in. They understood that they could not leave the premises and could not go to the village, so they kept asking when the bans would end. We did not know that. One cannot predict the constantly evolving situation. Actually, they are still asking us about that.

So the worst part is that you have nothing to answer. They ask: 'When will the visits be?' 'When will the relatives be able to come?'

However, a group of clients with mental disabilities do not have questions such as: 'What about our families and loved ones? Have they suffered from the disease?' This is mainly due to the fact that the majority of these clients do not have a family. The first thing which they started to address was the masks. Some of them, even legally competent ones, had quite a difficulty with it. It was difficult to explain them the danger of spreading the infection among clients who may be away from the centre and among our helpless seniors. However - with a few exceptions, we were able to explain the situation and persuade these clients.

\section{Distant Forms of Communication in the Day Care Centre}

During the interview with Respondent No. 1, I wanted to know whether video calls of seniors with relatives could become a fully-fledged alternative to visiting at a time of forced restriction of contact visits. Respondent No.1 compared the first and second pandemic waves in connection with the declining interest in making video calls.

Respondent No. 1: For us, the second wave is extremely different. In the first wave, a number of Skype calls were made, and relatives were interested in seniors in this way. Nothing is happening in this second wave. All communication is completely dead. This second wave has been going on for a long time. There is no attempt to communicate through video calls. It is strange... We used to carry laptops three times a day for Skype calls. Nothing like this is happening now.

Respondent No. 1 believes that there may be more reasons. In particular, it is the long duration of the second wave of the pandemic. Another possible reason, according to her, might be the specificity of video calls. They may not suit seniors.

Respondent No.1: One of the reasons is probably the very long duration of the second wave of the pandemic. Family ties are lost. As the family does not go to see its old relatives, the family ties break. Out of sight, out of mind.

Another (and perhaps more prosaic) reason is that most older clients (around eighty and, of course, ninety) have difficulty making a video call. They talk to the screen, but they look for relatives around their bed. Seniors do not understand the words from the speakers very often, and relatives have to ask repeatedly. Seniors cannot touch their children, they do not have them with them. Therefore, there is no way how to focus on them. They usually see the screen of the computer poorly. Thus: even relatives may get the impression that the skyping loses its meaning.

Respondent No. 1 is of the opinion that video calls are not a fully-fledged substitute for face-toface contact. She thinks, though, that all currently available means should be used.

Respondent No. 1: Personally, I think skyping is better contact than no contact at all. What is usually not missing is an auditory perception. For example, a senior hears 'Mom!', and this is, of course, very 
important. But now even this way of contact is missing, and I do not like it. Hopefully, this period will end soon and relatives will be able to start visiting our clients again after the summer.

A video call at the centre is almost always tied to the personal presence of activation workers. It is therefore, in principle, an unusual form of meeting.

Respondent No. 1: The point is that I have to prepare the laptop and put it on the senior's table above the bed. I then hold it there, because some seniors could knock it down and we also have a bad wi-fi signal which can get lost. Therefore, I sometimes have to reconnect the network and repeat the call. So I am usually with them for the duration of the video call. When they cannot hear or understand, I help with the message, or I repeat it... If, of course, the senior manages the device without any problems, we make an arrangement, and I leave them alone to have privacy.

Funny situations arise when, for example, you help a lady who is over ninety during a video call. You stand next to her and she says into the laptop: 'Sometimes the nurses pi.. me off pretty much...! And yesterday, the bitch came and she...!' And the daughter says to her: 'Shhhh, mum! Mom, she is standing next to you! Do not say that!' And the grandma says: 'Just let her hear it!' (Laughs). So video calling can be a lot of fun.

Respondent No. 2 reflects upon the reasons why the situation around video calls is somewhat different in a group of clients with mental disabilities.

Respondent No. 2: Video calls did not take place in our group in the first wave and do not take place even now. Younger clients have their mobile phones and make phone calls with their families by themselves. Even if they cannot control the devices themselves, they come to us and we dial a family member. Another reason for the lack of video calls is that many clients do not have family members at all, or have guardians only.

\section{Deaths of Clients}

Respondent No.1 mentioned, among other things, her childhood. She was raised by her great-grandmother and has been working in the environment of seniors all her life - now also professionally. According to her, the fates of 'her' clients affect her personally. She explained that seniors often confide in her and talk to her about very personal matters. According to her, she has gained their trust, because she, unlike 'non-educational' (medical) staff, has time for them. She confided that, as a result of a more personal relationship with clients, it is harder for her when they die. In her statements, she repeatedly described the frustration caused by the deaths of clients during the spread of the disease in the DCC.

Respondent No. 1: At the time of the covid virus, we lost fifteen clients in three weeks. At the time of the highest mortality of clients in the institution, I was also ill. I do not know if you can talk about luck in such a case, but when I returned to work after my illness, the situation was calmer. Within a short time period, men and women died. These were people who could have lived here for several happy years if they had not contracted the COVID-19 disease. Men around the age of 65, who had no disease other than compensated diabetes, died. A man with diabetes, a person full of optimism, suddenly 'got worse' within two days and did not wake up the next morning.

Of those fifteen, only three died in hospitals. The others died suddenly, mostly during the night. There were no symptoms and usually no fevers. Apparently, the viral infection was added to another disease and the client did not wake up in the morning.

It is traumatic for me. One sees clients every day and considers them a kind of family. They confide in you, trust you. And if so many people leave at once, a strong feeling of hopelessness awakens in you. 
One sees that the disease can kill so many people in such a short time.

Respondent No. 1 explains that, in the case of this disease, the most difficult thing is the unpredictability and suddenness of death.

Respondent No. 1: In most cases, when seniors 'are leaving' this world, you see it weeks in advance. These are clear signals: the expression and shape of the bones in the face change, the energy leaves him, and he stops eating. Everything is sudden with the coronavirus infection. You do not have time to talk to them. Suddenly, they are gone, it is sad.

Actually, I try not to say goodbye to dying patients in general, you do not want their last moments... Like this: I would cry, I know this about myself. That is why I try to encourage them even in these moments, to talk cheerfully, to discuss optimistic moments. So that they do not have to think of something bad when they are dying. If I were to discuss some sad topics with them, I would cry there in their presence, and I would definitely not help them much. And when I see them dying, I try to visit them more often, to spend even more time with them - even though there are another incredible number of other clients on the floor.

But in the case of current sudden deaths associated with this viral disease, I do not feel the best and I say to myself: 'Why did not I anticipate it? I could visit him, encourage him, or say something nice to him....

According to Respondent No. 2, reduced cognitive abilities in clients with mental disabilities affect the experience of the risk of a pandemic and the perception of death.

Respondent No. 2: In the first wave, we kept explaining everything to our clients. In reality, though, covid did not appear in the centre, so the danger for all of us was far away. In the second wave, the infection was brought to the centre and affected the fates and lives of clients to a large extent. Most clients went through covid, including the staff. Suddenly, clients' friends were dying unexpectedly. These were people who were definitely not expected to pass away. Some clients may have not been even fully aware of the deaths of their friends. This, though, may be an advantage for clients with mental disabilities, as they often do not understand the context. A friend just went to their hospital and never came back. I believe that some people do not combine the information together and thus are not able to realise that a friend who was in the hospital died. This makes clients with severe mental disabilities 'immune', as they do not solve the consequences of some phenomena.

\section{Vaccination as a Symbol of Hope}

Seniors in this centre may also experience a kind of frustration due to media coverage. It supplies the artificially closed DCC environment with a lot of negative information. Respondent No. 1 mentioned a very important factor that currently affects the way of experiencing the pandemic in the elderly: the onset of vaccination.

Respondent No. 1: Some clients already automatically change the channel when the news is on. There is too much for them. In the last 14 days, however, their pandemic experience has changed, as they underwent the first round of vaccination. They are optimistic and have the conscious sense that this difficult episode of life is coming to an end. And I do not have the heart to tell them that when they get a second vaccine, it does not mean that they can go past the gate of the day care centre. There is a feeling of hope that they will receive a second vaccine and everything will be allowed... But the situation does not correspond to that yet. That bothers me. We are worried. What will this do to some clients when they find out about the fact that the gates might not open and the closure would continue? 
When I asked Respondent No. 2 about the hope seen in this vaccination, she answered rather soberly and vaguely:

Respondent No. 2: I really do not know. I also got vaccinated. It was rather because of the opportunity and because of the clients I work with. But considering usefulness... I do not know, it is hard to say. I had no idea what the vaccine would do to me. The first dose did not kill me, so hopefully it will be good (laugh).

\section{Care of the Soul}

Respondent No.1 described a very fundamental thing: how essential activity and contact are for a person. An old person, who is very often confined to a bed, without the ability of movement, depends on verbal or haptic contact with others. Physical contact (in the form of stroking or holding hands, i.e., when relatives hold the hands of their elderly etc.) is thus a forbidden danger during anti-pandemic measures. This is frustrating for seniors, according to the respondents.

Respondent No.1: Movement therapy is still excellent for younger seniors. The park is maintained here, clients rake leaves, prune trees... They spend a lot of time doing that, usually all morning. I think that helps them a lot so that they do not get depressed completely.

This is not possible for elderly senior women. I try (when I see them) to bring them to reality, to say what day it is. Because when you just lie down all day and the last big moment of the day is dinner at five o'clock (plus at one o'clock at night someone comes to change your incontinence pad) and in the meantime you do not see anyone until the morning, it is an awfully long time.

For these senior women, not only verbal but also haptic contact is important. When they can touch you. This is very important. If you come and pet their hand, that touch means a lot to them. I also wrote in the essays that if we were making video calls using Skype, the seniors were talking to relatives on the screen, but I was holding their hand. If visits would be allowed, relatives would come, hold their hands, and talk to them.

And it is precisely this physical contact that they are woefully lacking in the time of anti-pandemic measures.

\section{Attitudes towards Anti-Pandemic Measures}

I asked Respondent No. 1 to try to express her relationship to the anti-pandemic measures as concretely as possible. These are currently the subject of media cases and disputes by academics. The respondent formulated her opinion on the basis of experience.

Respondent No. 1: I believe that the opinion of some people on the situation with the mentioned disease is limited by a lack of experience with more severe cases. Two colleagues from the staff of our day care centre ended up in hospital due to the dramatic course of the disease. In my opinion, discipline is appropriate. People who downplay the disease could try to help out for a fortnight in hospitals. I am surprised by the belittling. Of course: when I stayed home with the disease, I also infected my family members (which was proven). Thank God, my husband and daughter were asymptomatic. But not everyone is so lucky. The course of the disease might be asymptomatic once, but it can be different in the case of re-infection. We are such a rebellious nation: is it because we were 'under the thumb' for decades?... And so we need, in case of possible restrictions, to rebel. I really do not know. But in my opinion, in this case, we should think more about others.

The reason might be that generations have stopped living together. They do not meet so much, and the younger generation do not care much about their elderly. I really do not know. However, some 
illustrative cases are visible in my work. There are examples of grandmothers and grandfathers who have visits only on 'payday'. There are very rare cases of grandchildren visiting seniors. In the case of a 90-year-old senior, grandchildren are, in fact, the adults. If the grandchildren rarely arrive, it is evident that they are very nervous about the visit. They quickly run away after that. Personally, I live with my mother-in-law and the generations in our coexistence are connected. Considering my daughter, I can see that, perhaps thanks to the daily contact with her 70-year-old grandmother, she does not mind visiting me at my workplace. She naturally talks to the seniors. There is a different situation in a case of a child who does not have personal experience with regular visiting of a grandparentsenior and sees Grandma once every two months for an hour in an institutional facility...

\section{The Positives of the 'Covid' Period?}

My colleague and I collected 182 written essays at the Faculty of Theology of the University of South Bohemia. These works capture the students' attitudes towards the current situation affected by the COVID-19 pandemic. Authorial essays in which students of leisure pedagogy also perceived a certain positive challenge in the current situation appeared sporadically.

During the unstructured interview, the respondents also dealt with this issue, that is, whether they see something positive even in this difficult time through the prism of their experiences. They were assured, of course, that they did not have to construct their answer at all costs. Respondent No. 1 looks at the current situation using the perspective of her helping profession.

Respondent No. 1: This time can show a lot to people of working age, workaholics. Thanks to antipandemic measures, they have the opportunity to discover a pleasant time, i.e., to spend time together with their children and to be able to understand them. For seniors though, who spend time in institutions, there is nothing good about this period.

Someone may see something positive in it, I do not know. However, in our centre, we cannot even invite music, we cannot carry out canis therapy events... There is a desperate constitutional monotony that does not do clients any good.

I have a little bit of hope that summer could be normal. One must hope for something better. Otherwise, one would be depressed oneself (laughs). So when I see those senior women, I tell them: hold on, it will definitely get better! And they were so excited about the vaccination... So I support that enthusiasm. Considering the situation, the most important is not to get worse. So yes, I am optimistic. You have to be in this job. Otherwise you would have to quit the job eventually.

Based on her experience from DCC, Respondent No. 2 does not find this situation beneficial either. When I asked her to comment on the possibility of the positive impact of this infection on the clients and their family relationships, that is, the relatives of the clients would be more aware of the essential values, Respondent No. 2 replied rather sceptically.

Respondent No. 2: Not at all. Anyone who visited clients before will visit them again when the restrictions are lifted. Whoever visited our clients once a month only, typically on the fifteenth of each month, will visit them at that time again when they have the opportunity.

It mostly depends on how the family set it up from the beginning. Even a virus infection, which can be fatal, does not change relationships. I did not notice such a case where the family (not visiting the client before) realised the happiness connected to the survival of their family member (who had combated the COVID-19 infection in the centre) and began to appreciate the moments spent together with their relative in the centre. 


\section{Discussion and Conclusion}

The paper builds on data obtained from two respondents working in DCC. This centre is currently facing the problem of the disease and its spreading. Users of social services as well as centre workers are limited by measures aimed at preventing or at least slowing down the spread of the infection caused by the new type of coronavirus SARS-CoV-2.

As this is a new challenge, a new situation, its effects are currently being investigated. The aim of this paper was to capture authentic statements (in a specific environment with the help of qualitative research tools) and to try to avoid purposeful interpretations (which such a topic may lead to).

The respondents provided a starting point for this work: their story describing the dynamic development of the pandemic and the way in which the centre is influenced, limited, and affected by the current situation associated with COVID-19.

In their statements, they mentioned that the two waves of the pandemic situation are qualitatively different. Their argumentation is based on the fact that the disease spread in the centre during the second wave and had a severe impact on the lives of clients and on the respondents themselves in their personal and professional life. A research survey by Nádvorníková and Kliment also mentions a change in the perception of the epidemic and restrictive measures. They state that one of the factors for perceiving the situation as serious was fear. It typically intensified when a staff member became ill. ${ }^{25}$ The impact on the job role is described in the same spirit by Respondent No. 2: due to her colleagues' illness and the closure of the canteen, she had to carry out other work activities (e.g., buying cigarettes for clients, arranging communication with relatives of potentially ill clients, etc.) outside her employment duties.

The respondents are experiencing a situation of sudden deaths of clients caused by COVID-19, and it is very hard for them. It is also a well-known fact from psychological research. Experiencing events that are perceived by an individual as uncontrollable and unpredictable is particularly difficult. ${ }^{26}$ Jankovský draws attention to the dark side of the institutional model of cold, material, depersonalised professional care. ${ }^{27}$ In contrast to this risk (which can be considered a price paid for professionalisation in the helping professions), we perceive the statements of Respondent No. 2 and her participatory interest in clients.

The report of the working group of the Government Council for Mental Health, which mapped the effects of the crisis caused by COVID-19 on the mental health of the Czech population, states that the institutionalised population, including people with disabilities, seniors in institutions, etc., was hit hard by the restrictive measures. Namely, they mainly suffered due to social isolation caused by restrictions on free movement, resp. by a ban on visits. The report states that the institutions were unprepared and managed the situation intuitively. ${ }^{28}$ The respondents clarified the communication and added the findings from their practice: anti-pandemic measures are experienced qualitatively differently by different groups of users of social services. Clients with mental disabilities experience the situation according to the degree of their cognitive abilities and the

5 Cf. Pavel KLIMENT and Lenka NÁDVORNÍKOVÁ, 'Prvotní reflexe....

26 Cf. Rita ATKINSON, Psychologie, Praha: Portál, 2003.

27 Cf. Jiří JANKOVSKÝ, Etika pro pomáhající profese, Praha: Triton, 2018, p. 155.

28 Cf. (C) Dopady krize způsobené koronavirem SARS-CoV-2 a duševního zdraví populace ČR - zpráva pracovní skupiny Rady vlády pro duševní zdraví (online), available at: https://www.mzcr.cz/wp-content/uploads/2020/01/Dopady-krize-zp\%C5\%AFsoben\%C3\%A9koronavirem-SARS-CoV-2-a-du\%C5\%A1evn\%C3\%ADho-zdrav\%C3\%AD-populace-\%C4\%8CR.pdf., cited 20 ${ }^{\text {th }}$ April 2021. 
degree of institutional deprivation. In users of social services, the degree of frustration depends on their individual needs (illustrated by the case of a client who cannot perform his 'walking ritual' after breakfast because the gates of the centre are closed). The respondents mentioned that possible frustration can be relieved, for example, by physical activity in the area of the complex, activation activities, haptic contact (in the case of disabled seniors confined to bed), mediated contact with relatives with the help of video calls, or increased dosage of medication.

While the report of the working group of the Government Council for Mental Health recommends the provision of at least online contact of clients with the external social environment as an example of 'good practice', the respondents experienced a particularly difficult situation when considering the isolation of senior clients. In their case, video calls cannot mediate full contact. The respondents stated that the quality of meeting with seniors through video calls is influenced by the necessary presence of centre workers (who help with technology but can also disturb the privacy of callers) and by the limited ability of seniors to adapt to this type of distance meeting with their relatives. Apparently, these factors also influenced the lower frequency of video calls in the second wave of the pandemic (which is still in progress). In the interviews, the respondents described, for example, the drama of situations: senior clients meet their family members through an arranged technique that is 'operated' by a social worker. She must be present during the video call to assist and eliminate 'technical issues'. While the senior speaks to the screen, which he often sees poorly and does not hear the sound from the speaker due to hearing loss, the lack of haptic contact is 'replaced' by the social worker. She holds the senior's hand during the video call. In this spirit, Respondent No. 1 talked about the problem of 'haptic isolation' of senior clients. It is a feeling of loneliness arising from the absence of physical contact which a video call cannot solve. The respondents reflected on the current vaccination of risk groups, as it is changing the way of experiencing the current difficult situation, and it gives hope to senior clients of the centre. At the same time, Respondent No. 1 mentioned that the vaccination of seniors is not a tool leading to the alleviation of current measures. This is, so far, a taboo in this institute for understandable reasons (the mental well-being of clients).

The research survey by Nádvorníková and Kliment mentions that some social workers tended to take the situation lightly, underestimate it, and did not understand the necessity of quarantine measures. ${ }^{29}$ The informants in our research believe that the opinion of individuals who tend to downplay the situation and the need for restrictive measures is limited by the lack of experience with more severe cases of the disease. Respondent No. 1 is of the opinion that discipline is appropriate: she argues using difficult cases from her surroundings and the fact that she became infected in social services and then passed the infection on to her family members.

The respondents do not see (from the perspective of their experience in the helping profession) any significant positives in situations caused by the current pandemic. They defend their opinion mainly using the facts like frustration connected with the needs of clients in their workplace and fear for their loved ones.

Statements given by respondents had an impressive overlap into interpersonal relationships in which the social worker is 'professionally involved'. While in some research probes focused on the pedagogical environment the situation is evaluated positively (for example, distance learning as a positive challenge for teachers and parents, the possibility of spending time together, etc. ${ }^{30}$ ),

29 Cf. Pavel KLIMENT and Lenka NÁDVORNÍKOVÁ, 'Prvotní reflexe....

30 Cf. Roman ŠVA ŘICČEK, Jana STRAKOVÁ, Cyril BROM, David GREGER, Tereza HANNEMANN, Jiří LUKAVSKÝ, Mandatory home education during the COVID-19 lockdown in the Czech Republic: A rapid survey of 1st - 9th graders' parents, Frontiers in Education 5/2020, pp. 1-8. 
in the DCC environment respondents evaluate the situation as very serious and difficult. The reason can be seen in the fact that the infection of clients in the centre is a potential life threat for the vulnerable group there. The respondents do not believe that the current crisis will help family members to reflect on 'real values' and that the broken relationships (which the respondents witness) are harmonised again due to the relief of relatives realising that their loved one in the DCC survived the virus infection that could have been lethal.

General recommendations for practice can be found in the materials that mapped the impacts on the mental health of workers in the helping professions. ${ }^{31}$ In our article, it is possible, thanks to the statements of the respondents, to decipher the subtle nuances of practice in social services that the serious situation has brought. The respondents also reflected on very difficult situations (clients dying, trying to encourage those who are suffering due to the current emergency situation, etc.). We believe that the illustration of this practical experience can help to gain a more comprehensive understanding of the specifics and demands of the profession whose 'tool' is the human relationship and actions of specific individuals.

\section{Contact}

\section{Dr Josef Nota}

University of South Bohemia in České Budějovice

Faculty of Theology

Department of Education

Kněžská 8, 37001 České Budějovice

jnota@tf.jcu.cz 